\title{
Evolution pathways of employees' work on dairy farms according to task content, specialization, and autonomy
}

\author{
Priscila Duarte Malanski ${ }^{*}$, Nathalie Hostiou and Stéphane Ingrand \\ Université Clermont Auvergne, AgroParisTech, Inra, Irstea, VetAgro Sup, Territoires, 63000 Clermont-Ferrand, France
}

\begin{abstract}
Evolution of employees working on dairy farms is related to the increase in farm size and the decrease in the size of family workforce. Thus, maintaining employees on dairy farms is a major problem for dairy farmers. We hypothesize that maintaining employees is related to their evolution pathways of work according to the tasks assigned, the level of versatility $v s$. specialization and the level of autonomy. Our aim was to describe different pathways for employees according to these three dimensions of work. Eight farmers and 14 permanent employees on eight French dairy farms were interviewed individually. Eight variables were identified to describe the evolution of tasks assigned to employees, the trend toward versatility vs. specialization, and the evolution of autonomy. Five evolution pathways of employees' work were identified. The longer-term goal is to discuss these results with farmers, employees and agricultural advisors to validate the results and assess their usefulness in a reflexive process concerning employees' career on farm.
\end{abstract}

Keywords: work / hired labor / permanent labor / dairy farms / France

\begin{abstract}
Résumé - Trajectoires d'évolution du travail des salariés dans les élevages bovins laitiers selon le contenu des tâches, le niveau de spécialisation et d'autonomie. Le développement du salariat dans les élevages laitiers est lié à l'agrandissement des exploitations et à la diminution de la main-d'œuvre familiale. Ainsi, pérenniser les salariés sur les exploitations laitières est un enjeu pour les éleveurs. Notre hypothèse est que la pérennisation des salariés relève de leurs trajectoires d'évolution du travail, que nous caractérisons par trois dimensions: l'attribution de tâches, la polyvalence vs la spécialisation et le degré d'autonomie. Notre objectif est de décrire les différentes trajectoires possibles pour des salariés en tenant compte de ces trois dimensions du travail. Huit éleveurs et 14 salariés permanents de huit exploitations laitières françaises ont été interrogés individuellement. Huit variables décrivent les évolutions dans les tâches attribuées aux salariés, la tendance vers la polyvalence $v s$ la spécialisation et l'évolution du niveau d'autonomie. Cinq types de trajectoires d'évolution du travail des salariés ont été identifiés. Les perspectives de ce travail sont de discuter ces résultats avec les employeurs, les salariés et les conseillers, afin d'évaluer leur utilité dans un processus réflexif sur la carrière des salariés en élevage.
\end{abstract}

Mots clés : travail / main-d'œuvre salariée / main-d'œuvre permanente / exploitation laitière / France

\section{Introduction}

Hiring employees has become more common on dairy farms due to the increase in farm size and the decrease in the size of family workforce (Blanc et al., 2008). In France, the number of employees has increased by $2.3 \%$ per year on dairy farms since 2000 , compared to increasing by $0.9 \%$ per year on pig farms and decreasing by $0.4 \%$ per year on crop farms (Agreste, 2014). The number of permanent employees on dairy farms is increasing greatly, especially to milk cows, one of the

\footnotetext{
*Corresponding author: priscilamalanski2@gmail.com
}

most important tasks, requiring a large, highly skilled and regular workforce (Stup et al., 2006).

However, maintaining employees is an issue for dairy farmers to keep hold of their farms over time in a context of smaller family workforces (Nettle, 2012). Employee turnover is related to the seasonality of farm activities and mainly to employees' low qualifications and skills (Cahuzac and Détang-Dessendre, 2011; Bellit and Détang-Dessendre, 2014). According to the same authors, only $30 \%$ of employees with fixed-term contracts receive permanent contracts; on average, permanent employees work on the same farm during three years.

Thus, decreasing employee turnover is a major issue for dairy farmers, because when permanent employees leave the 
Table 1. Characteristics of the eight farms in the sample.

Tableau 1. Caractéristiques des huit exploitations de l'échantillon.

\begin{tabular}{|c|c|c|c|c|c|}
\hline Farm & Types of production & Farm size (ha) & $\begin{array}{l}\text { Number of } \\
\text { dairy cows }\end{array}$ & $\begin{array}{l}\text { Number of } \\
\text { employees }\end{array}$ & $\begin{array}{l}\text { Number of } \\
\text { full-time family } \\
\text { workers }\end{array}$ \\
\hline 2 & Milk & 115 & 80 & 1 & 1 \\
\hline 3 & Milk & 140 & 90 & 1 & 2 \\
\hline 4 & Milk and cereals & 260 & 130 & 1 & 3 \\
\hline 6 & Milk and cheese & 115 & 60 & 2 & 1 \\
\hline 7 & Milk and cheese & 110 & 160 & 3 & 2 \\
\hline 8 & $\begin{array}{l}\text { Milk, cheese (cow and goat) } \\
\text { and cereals }\end{array}$ & 292 & 12 & 4 & 3 \\
\hline
\end{tabular}

farm before the end of their contracts, farmers have to deal with a loss of technical skills and search for and hire new employees with skills matching the work to be performed (Bitsch et al., 2006; Greenhalgh and Tipples, 2013). This situation is particularly tense on dairy farms because of the consistently high workload due to routine work (milking two or three times a day, feeding and animal care) associated with seasonal work peaks during the year (Cournut and Chauvat, 2012).

Several factors contribute to employee retention on farms, such as wages and benefits (Przewozny et al., 2016), adequate and safe working conditions (Porter, 1993; Jago et al., 2007; Harrison and Getz, 2015) and a good professional relationship between employees and farmers (Nettle et al., 2005). Previous studies, however, ignore dynamic aspects of work, such as changes in the division or the schedule of work and how interactions at the farm level change work organization over time. Therefore, considering the evolution of permanent employees' work is a relevant way to better reflect upon their careers on farms by improving their working conditions and decreasing the frequency with which they leave farms before the end of their contracts (Nettle, 2012; Moffatt, 2016).

Task assignment is important for organizing work at the farm level and defining employee tasks and responsibilities (Hutt and Hutt, 1993; Vafaï and Anvar, 1998). Versatility and specialization are different ways to organize work and the workforce. Versatility means that employees can perform several jobs, while specialization means that employees perform only one job (Everaere, 2008). A job is defined as a group of tasks with specific characteristics (Tourmen, 2007). Autonomy is defined as the degree of freedom that employees have over their work (Everaere, 1999). Employees' jobs and autonomy are strongly related to their tasks (Everaere, 2006; Everaere, 2008; Attia et al., 2012). For example, specialized employees working on pig farms perform important technical tasks such as artificial insemination, some veterinary care and technical monitoring of animal production; they have freedom to plan and perform their work. In contrast, versatile employees perform routine tasks such as cleaning buildings and distributing feed according to pre-defined instructions (Depoudent et al., 2014).

We hypothesize that there are diverse pathways of evolution of employees' work and that this diversity is related to changes in three dimensions of work: tasks assigned to employees, their level of versatility or specialization and their level of autonomy. The aims of this study were thus to identify

- variables describing these three dimensions;

- the diversity of pathways of employees' work on dairy farms.

\section{Materials and methods}

\subsection{Sampling criteria}

Since we had no assumptions about the factors and conditions related to farm or employee characteristics that generate different evolution pathways of employees' work, we selected situations as different as possible according to farm characteristics and work content. We chose a small number of farms to be able to describe each situation as precisely as possible. Thus, dairy farms with permanent employees were sampled according to three criteria:

- geographic area (mountains or lowlands);

- farm type (specialized dairy farm or diversified farm with milk production);

- composition of the teamwork.

To identify evolution of employees' work, we used two criteria to select permanent employees: work schedule (e.g. full-time, part-time, twice a week) and time since being hired (1-15 years). We understand as permanent employee those who work regularly in a dairy farm during one year at least.

\subsection{Data collection}

Eight farmers were interviewed from November 2014 to February 2015 about division of tasks over time, task instructions, the composition of the teamwork, employee recruitment, changes in employees' work, and farm trajectory (changes in structure, the herd, equipment, and teamwork). These farmers hired 14 employees ( $1-4$ employees per farm) (Tab. 1). These employees were interviewed from November 2015 to February 2016 about changes in their tasks performed over time, reasons for these changes, consequences of these 
changes on their work (tasks performed and work schedule), technical education in agriculture and professional experience.

\subsection{Sample description}

The sample was composed of 14 employees working on eight dairy farms in Auvergne, in France. The nine men and five women were aged 22-50 and were hired from 1998-2014. Eleven employees had technical education in animal production or farm machinery with professional experience in agriculture (at least one year), while three had neither technical education nor agricultural jobs before recruitment. Seven were full-time employees working $40 \mathrm{~h} /$ week, three were full-time employees working in an employer group ( $15 \mathrm{~h} /$ week) and four were part-time employees working $25 \mathrm{~h} /$ week.

Mean area and number of dairy cows of the eight dairy farms ( 150 ha and 93, respectively) were larger than those of all dairy farms in Auvergne (62 ha and 36, respectively) (Agreste, 2012). One farm had only 12 dairy cows but 250 dairy goats (it was excluded when calculating the mean number of cows) (Tab. 1). Thus, our sample was composed mainly of young, male employees working on large farms, in agreement with regional and national characteristics of the employee workforce in agriculture (Agreste, 2013; Bellit and Détang-Dessendre, 2014).

\subsection{Data analysis}

Data analysis was composed of three main steps. First, each interview was transcribed in full, and data from interviews, both with the farmer and the employee(s) working on the farm, were compiled into one monograph per employee. Monographs were organized according to the three dimensions that describe evolution pathways of employees' work: task assignment, specialization $v s$. versatility, and autonomy. Analyses of data from farmers concerned work organization (division of tasks, factors that make assigning tasks more difficult or easier, instructions given to employees about how perform tasks), changes in employee specialization or versatility and farm trajectory (changes in structure, the herd, equipment, and teamwork). Analyses of data from employees concerned changes in tasks assigned and reasons for these changes, the task schedule, conditions for performing tasks (with or without family farmers, room to manoeuvre for initiatives) and technical skills (education, professional experience).

Second, variables and categories for the three dimensions describing the evolution pathway of employees' work were identified by comparing employees (Girard et al., 2001). For each dimension, the two most different employees were compared to identify the variables. The categories were built progressively by considering the other employees until no additional variables or categories were identified.

Third, the categories of each variable were combined in a graphic representation (Bertin, 1977) to distinguish multiple pathways of employees' work. To do so, a "Bertin table" was built: each line represents one employee, and each column represents one variable. Each cell displays the category for one variable for each employee. A color gradient (white, gray and black) was used to distinguish the categories of each variable, with darker colors indicating more change for the given variable or pathway.

\section{Results}

\subsection{Variables to describe evolution of employees' work}

Eight variables and 19 categories were identified to describe the evolution of employees' work according to:

- task assignment, which indicates changes in tasks performed;

- versatility/specialization, which indicates changes in jobs;

- autonomy, which indicates evolution in working conditions (Tab. 2).

The distribution of employees per category was unequal despite their diversity. Thus, assigning more tasks to employees over time was common among farmers, sudden changes in employees' job were common, and most employees continued to perform tasks according to strict instructions without room of manoeuvre for initiatives (Tab. 2).

\subsection{Evolution pathways of employees' work on dairy farms}

Five main evolution pathways of employees' work were identified based on the diversity in our sample (Tab. 3). These pathways represent different ways that employees' careers on farms have developed according to the evolution of tasks assigned to them, their level of specialization and their level of autonomy.

Pathway 1 - Continuing to perform daily tasks ( 3 employees): at recruitment, the employees performed a few execution tasks with recurring frequency, such as daily milking, feeding and cheese making. Over time, they continued to perform the same tasks every day. Thus, they remained specialized employees, since the number of jobs that they performed did not change. These employees always had a low level of autonomy: since recruitment, they each worked in a pair with a farmer and had to follow strict task instructions, which helped farmers to maintain high control of tasks. The element explaining this pathway was the employees' lack of technical skills: they had no professional training in agriculture, and this was their first farm job. At recruitment, a farmer worked with them all day for weeks to teach basic technical skills about milking, feeding and cheese making. However, the main farmer worked intermittently on the farm because he was often busy with off-farm activities. His temporary unavailability to work on the farm, along with the low technical skills of the employees, maintained the strict instructions to employees performing tasks and recurring task control by farmer on every task performed by employees. Farm structure (herd and farm size) did not change after recruitment, which contributed to stability of the pathway. The employees had successive fixedterm contracts to work full-time on the same dairy farm that produced cheese in the mountains. They were non-agricultural workers that had long experience with agricultural activities (at 
Table 2. Variables by dimension, categories by variable, and number of employees identified per category in the sample of 14 employees on the eight dairy farms.

Tableau 2. Variables par dimension, modalités par variable et nombre de salariés identifiés par modalité dans l'échantillon de 14 salariés sur 8 exploitations laitières.

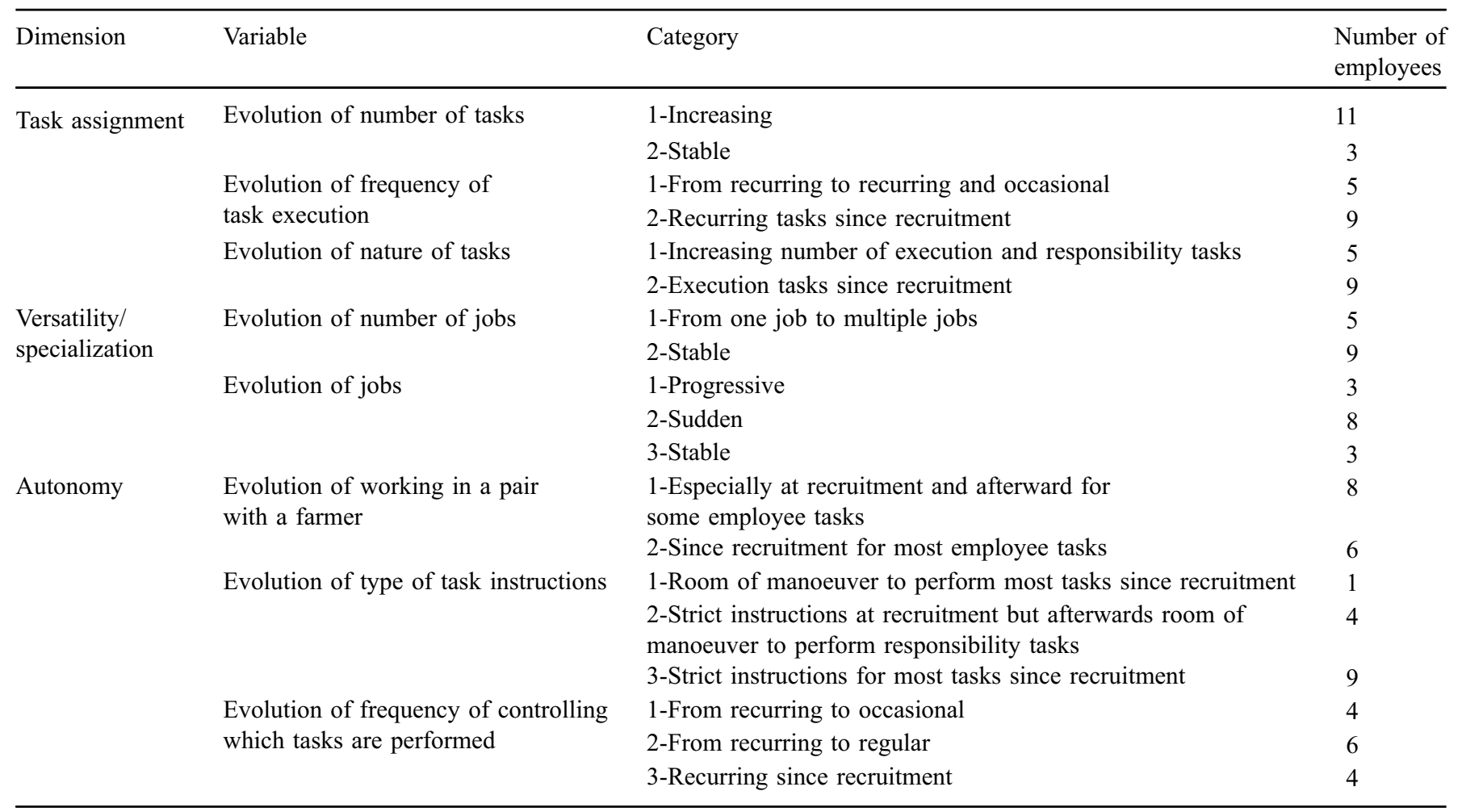

least two years). They worked in a large team composed of themselves, two farmers and five volunteer family workers.

Pathway 2 - Increasing versatility to perform all routine tasks (2 employees): at recruitment, the employees performed several execution tasks with recurring frequency to keep the dairy farm running, such as daily feeding and silage making and crop harvesting every summer. Over time, they performed more tasks with recurring frequency, such as soil preparation, sowing, and herbicide application. All tasks performed after recruitment were execution tasks. This evolution progressively increased their versatility due to the diversity of tasks and the stability of jobs. Reasons for this evolution were an increase in herd and farm size due to the arrival of an associate family farmer several years after the employees were recruited. Since recruitment, they each worked in a pair with a farmer for most tasks, following strict instructions to perform tasks and remaining under regular control by a farmer on most task performed by employee, such as monitor milking every weekend. Over time, factors such as shared workload and the increase in herd and farm size, kept employees and farmers working in a pair for several tasks, with strict instructions for performing them. The employees had permanent contracts working full-time on diversified farms producing milk in the lowlands. They worked in large teams composed of themselves and three farmers.
Pathway 3 - Becoming a versatile employee for occasional replacement (4 employees): at recruitment, the employees specialized in performing a few execution tasks with recurring frequency, such as daily cheese making or seasonal tasks during the year, such as haymaking in the summer and manure spreading in the winter. However, they suddenly became versatile employees: after the first year, the number of tasks performed occasionally, such as milking, feeding and selling cheese at the local market, increased slightly. Reasons for this evolution were a decreased workforce due to farmers' health problems and off-farm activities. The sudden increase in employees' versatility was induced by the occasional need to perform daily tasks (milking) or regular tasks (selling cheese) to replace farmers in case of an unexpected or occasional event. Employees had low autonomy in this pathway: they each always worked in a pair with a farmer to share the daily routine workload (cheese making) and seasonal workload (haymaking), and they had to follow strict instructions for performing most tasks under recurring control of a farmer, especially when replacing one of the farmers on milking, or under regular and planned control of a farmer, such as when employees replacing one farmer on selling cheese on local market. The element explaining this evolution was the organization of work to manage a decreased workforce during certain events. The employees had permanent contracts, but 
Table 3. Five evolution pathways of employees' work according to 14 employees (rows) and eight variables (columns). Numbers in cells refer to categories describing evolution of employees' work since recruitment (Tab. 2). Darker cells indicate more change for the given variable, which when read horizontally, indicate more change for the given pathway.

Tableau 3. Cinq trajectoires d'évolution du travail des 14 salariés (lignes), selon la combinaison des modalités des huit variables (colonnes). Le chiffre dans les cellules correspond à la modalité pour une variable donnée (Tab. 2). Plus le chiffre est petit (cellule plus sombre) plus les changements sont nombreux, pour la variable (colonne) et pour la trajectoire (ligne).

\begin{tabular}{|c|c|c|c|c|c|c|c|c|c|c|}
\hline \multirow[b]{2}{*}{ 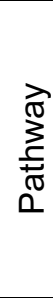 } & \multirow[b]{2}{*}{ 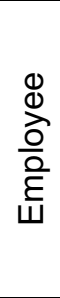 } & \multirow[b]{2}{*}{ 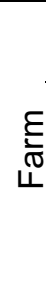 } & \multicolumn{3}{|c|}{ Task assignment } & \multicolumn{2}{|c|}{$\begin{array}{c}\text { Versatility/ } \\
\text { specialization }\end{array}$} & \multicolumn{3}{|c|}{ Autonomy } \\
\hline & & & $\begin{array}{c}\text { Evolution } \\
\text { of } \\
\text { number } \\
\text { of tasks }\end{array}$ & $\begin{array}{l}\text { Evolution } \\
\text { of } \\
\text { frequency } \\
\text { of task } \\
\text { execution }\end{array}$ & $\begin{array}{l}\text { Evolution } \\
\text { of nature } \\
\text { of tasks }\end{array}$ & $\begin{array}{c}\text { Evolution } \\
\text { of } \\
\text { number } \\
\text { of jobs }\end{array}$ & $\begin{array}{c}\text { Evolution } \\
\text { of jobs }\end{array}$ & $\begin{array}{c}\text { Evolution } \\
\text { of } \\
\text { working } \\
\text { in a pair } \\
\text { with the } \\
\text { farmer }\end{array}$ & $\begin{array}{l}\text { Evolution } \\
\text { of type of } \\
\text { task } \\
\text { instructions }\end{array}$ & $\begin{array}{l}\text { Evolution } \\
\text { of } \\
\text { frequency } \\
\text { of task } \\
\text { proceeding } \\
\text { control }\end{array}$ \\
\hline \multirow{3}{*}{1} & 8 & \multirow{3}{*}{7} & 2 & 2 & 2 & 2 & 3 & 1 & 3 & 2 \\
\hline & 6 & & 2 & 2 & 2 & 2 & 3 & 2 & 3 & 3 \\
\hline & 7 & & 2 & 2 & 2 & 2 & 3 & 2 & 3 & 3 \\
\hline \multirow[b]{2}{*}{2} & & & 1 & 2 & 2 & 2 & 1 & 2 & & \\
\hline & 11 & 8 & 1 & 2 & 2 & 2 & 1 & 2 & 3 & 2 \\
\hline & & & & & & & & & & \\
\hline \multirow{4}{*}{3} & 1 & 1 & 1 & 1 & 2 & 1 & 2 & 1 & 3 & 2 \\
\hline & 10 & 6 & 1 & 1 & 2 & 1 & 2 & 1 & 3 & 3 \\
\hline & 3 & 3 & 1 & 1 & 2 & 1 & 2 & 2 & 3 & 2 \\
\hline & 14 & 8 & 1 & 1 & 2 & 1 & 2 & 2 & 3 & 3 \\
\hline \multirow{4}{*}{4} & 9 & 6 & 1 & 2 & 1 & 2 & 1 & 1 & 1 & 1 \\
\hline & 2 & 2 & 1 & 2 & 1 & 2 & 2 & 1 & 2 & 1 \\
\hline & 12 & 8 & 1 & 2 & 1 & 2 & 2 & 1 & 2 & 1 \\
\hline & 13 & 8 & 1 & 2 & 1 & 2 & 2 & 1 & 2 & 1 \\
\hline 5 & 5 & 5 & 1 & 1 & 1 & 1 & 2 & 1 & 2 & 2 \\
\hline
\end{tabular}

with different work schedules (full-time, part-time or twice a week as shared employees), and worked on specialized dairy farms producing cheese in the mountains or on diversified farms in the lowlands. The size and composition of teams were diverse: small (one employee and one farmer), medium (one employee, two farmers and two volunteer family workers) and large (four employees and three farmers).

Pathway 4 - Becoming a highly skilled dairy farm technician (4 employees): at recruitment, employees performed a few execution tasks with recurring frequency, such as daily milking. After the first year, they started to perform more tasks, mainly with technical responsibilities for animals, such as heat detection, monitoring animal health, and some veterinary care. These changes suddenly increased their level of specialization. Reasons for this evolution were an increase in herd size and retirement of a family farmer. Thus, with more animals and fewer workers, farmers gave more technical responsibilities to employees to take care of animals, which increased the latter's autonomy rapidly. Task instructions changed from only strict instructions for execution tasks at recruitment to more room of manoeuvre to perform responsibility tasks. Working in a pair with a farmer was reduced to a few tasks, especially milking.
At recruitment, the frequency of control by farmers on tasks performed by employees was also recurring but over time became occasional. Elements explaining this evolution were the employees' technical skills, which were developed in previous positions, and farmers using their own experience to teach them other techniques. The departure of a family farmer required distributing his tasks to others; the remaining farmer preferred to retain the versatility to monitor all activities on the farm and to increase employees' specialization by increasing their technical responsibilities. The employees had permanent contracts working full-time or twice a week as shared employees, or they had fixed-term contracts working parttime. They worked on specialized dairy farms with or without cheese production in the mountains or on diversified farms in the lowlands. The size and composition of teams differed: small (one employee and one farmer) or large (several employees and three farmers; one employee, one farmer and several volunteer family workers).

Pathway 5-Becoming a farmer (1 employee): at recruitment, the employee performed some execution tasks with recurring frequency to keep the dairy farm running, such as milking and feeding every day. Over time, he performed 
more tasks, including tasks with technical responsibilities, such as heat detection and selection of breeding bulls. This evolution occurred due to the small family workforce and high workload. Furthermore, the farmer's health problems and the employee's request to perform more tasks encouraged the farmer to assign him more tasks. His work suddenly became more versatile, with several tasks performed over the entire dairy farm, such as haymaking, silage making, manure spreading, some veterinary care, support for calving, and declaration of calf births. Over time, fewer tasks were performed in a pair with the farmer. The frequency of task control by farmers on tasks performed by employees also decreased from recurring to regular control. The employee had strict instructions at recruitment for execution tasks, such as milking, but over time the employee had increased room of maneuver to perform responsibility tasks, such as selection of breeding bulls. These changes increased employee autonomy. The main factors explaining this pathway were:

- the farmer's desire to have an associate farmer;

- the employee's wish to become a farmer;

- use of technical skills that the employee acquired from technical training and professional experience before recruitment and from developing new technical skills by practicing with the farmer. The employee had a permanent contract working full-time with the farmer. They worked on a specialized dairy farm in the mountains.

Farms with more than one employee had different ways to develop employees' careers. All employees could have the same pathway, such as on farm 6, which had three employees on pathway 1 . Alternately, they could have different pathways, such as on farm 8 , which had two employees on pathway 4 and one employee each on pathways 3 and 2 (Tab. 3). The main factors explaining these differences were related to:

- the farmers' views about how to manage employees' work, such as the degree of specialization and autonomy to perform tasks;

- the employees' views about the adequacy of their technical skills and their level of specialization.

\section{Discussion}

Task assignment, versatility/specialization and autonomy are relevant for better describing and understanding evolution of the work of permanent employees on dairy farms because they allow identification of changes in employees' work and employees' roles in teams. This approach to analyzing evolution of work in livestock systems is original because most other approaches and methods highlight technical practices during the year to describe work organization at the farm level (Dedieu et al., 2006; Madelrieux et al., 2009). Another unique characteristic of the approach is the consideration of dynamic aspects of work. The eight variables and 19 categories identified changes in quantitative and qualitative characteristics of employees' work. Previous studies analyzed employees' work by considering only its static aspects, such as working conditions (Porter, 1993; Harrison and Getz, 2015).

Five pathways of permanent employees' work on dairy farms in Auvergne were identified using a dynamic approach assessing three dimensions of work: task assignment, versatility $v s$. specialization and autonomy. Three pathways increased employee versatility, which confirms that some farmers want versatile permanent employees, especially on dairy farms in mountain areas (Dupré, 2010). Versatile employees provide flexibility when organizing teamwork (Mundler and Laurent, 2003) by sharing the workload of routine tasks (pathways 4 and 5) or by replacing farmers during unexpected events (illness) or planned events (professional meetings) (pathway 3).

Two pathways concerned employees specialized in milk production. Most employees on dairy farms are hired to milk cows (Porter, 1993; Bewley et al., 2001; Mugera and Bitsch, 2005). One way to develop careers of specialized employees is to improve their technical skills in animal care (pathway 4). On large dairy farms, doing so provides employees who milk cows an opportunity to become promoted as herd managers (Harrison and Getz, 2015). However, employees without qualifications or few technical skills are commonly assigned to perform a few routine tasks (pathway 1). Similar cases were identified for immigrant employees who milk and feed cows on large dairy farms (Krissman, 1995; Hyde et al., 2011).

Increasing autonomy was identified only in pathways in which employees had a degree of freedom for some tasks with technical responsibilities (pathways 4 and 5). However, studies have shown that strict instructions for routine tasks, such as standardized milking procedures to monitor milk quality (somatic cell score) (Bewley et al., 2001; Hyde et al., 2008; Harrison and Getz, 2015) increase the quality of employees' work. Thus, pathways of employees performing execution tasks with low autonomy (pathways 1, 2 and 3), depending on their career goals, do not necessarily represent negative working conditions.

Pathway 5 represents employees transitioning in their professional careers to become associate farmers on the farms they work. It is one way to improve technical skills and start learning about administrative procedures. This pathway is common for employees on livestock farms (Madelrieux et al., 2010), especially for permanent employees, because hiring employees is one way for farmers to seek new associate farmers (Madelrieux et al., 2009). In contrast, on pig farms, remaining a permanent employee over time can be a true professional career (Madelrieux and Depoudent, 2015).

Factors of evolution of employees' work are related to several changes. As identified for pathways 4 and 5, changes in the workforce, especially the departure of family farmers, is a chance for employees to become more responsible for their work (Madelrieux et al., 2009). Moreover, temporary unavailability of farmers to work (illness or meetings) may lead to employees replacing farmers regularly (pathway 3 ). This is a current practice among shared employees and farmers of employer groups (Chabanet et al., 2000). In addition, other studies confirm our results demonstrating that structural changes on farms (increase in herd and farm size) affected the work of farmers by changing routine tasks (pathway 2), such as feeding (Aubron et al., 2016) and grassland management (Moulin et al., 2004). Moreover, improving technical skills is a strong way to develop employee careers (pathways 4 and 5) (Everaere, 2006; Abdallah and Ammar-Mamlouk, 2011). As we identified, employees develop their skills by practicing with farmers after recruitment. Thus, they can learn by performing 
tasks throughout their career on the farm (Gaudart and WeillFassina, 1999).

These pathways could be used by agricultural advisors as an advisory tool to illustrate the diverse possibilities of employees' careers at two points:

- before recruitment, when farmers and agricultural advisors could discuss how to better define the roles of employees on farms (e.g., routine tasks to be performed, room for manoeuvre to take initiative, degree of specialization) according to farmers' needs;

- after recruitment, when farmers, employees and agricultural advisors could discuss how to identify better ways to develop employees' careers by considering the latter's wishes and farmers' needs. Thus, using the pathways in an advisory process may help keep employees working on farms by decreasing effects of a career that employees feel is in decline.

\section{Conclusion}

Pathways of employees' work were described in three dimensions: task assignment, versatility/specialization and autonomy. Eight variables and 19 categories were built to describe these three dimensions. Five pathways were identified based on these variables. These pathways highlighted diverse ways that employees' careers on farms can change over time and described roles of employees in farm teamwork. We conclude that task assignment, versatility/specialization and autonomy are pertinent for better describing and understanding the evolution of the work of permanent employees on dairy farms because they describe consequences of changes in their work. Factors explaining changes in employee careers on dairy farms were also identified and classified into changes in farm structure, changes in the workforce, and employee wishes.

Understanding how the work of permanent employees evolves could help to improve their work and decrease employee turnover by guiding farmers and employees to develop the latter's career on farms. The longer-term goal is to discuss these results with farmers, employees, and agricultural advisors to validate the pathways and assess their usefulness for an advisory process concerning employee careers on farms. This process can start before recruitment with a reflexive discussion between farmers and advisors to match farmers' needs with potential roles of employees on farms. Then, the process can be useful after recruitment by including employees in a regular reflexive discussion with farmers and advisors to identify better ways to encourage employees to continue working on farms.

Aknowlegedments. This work was carried out with the support of Science without Frontiers, from CAPES and Ministry of Education of Brazil. Partners of this work: RMT Travail, Fédération Nationale des Syndicats d'Exploitants Agricoles and the Syndicat Interprofessionnel Saint Nectaire.

\section{References}

Abdallah LB, Ammar-Mamlouk ZB. 2011. Changement organisationnel et évolution des compétences. La Revue des Sciences de Gestion 4(226-227): 133-146.
Agreste. 2012. Recensement Agricole 2010. Deux vaches nourrices pour une vache laitière sur les herbages auvergnats. GraphAgri. http://agreste.agriculture.gouv.fr/IMG/pdf/R8312A17.pdf.

Agreste. 2013. Population agricole, formation et recherche. GraphAgri. http://agreste.agriculture.gouv.fr/IMG/pdf/Gaf13p036-041. pdf.

Agreste. 2014. Le bilan annuel de l'emploi agricole selon l'orientation technico-économique de l'exploitation: Résultats 2012. http://agreste.agriculture.gouv.fr/IMG/pdf/parti e1cd225bspca.pdf.

Attia E-A, Dumbrava V, Duquenne P. 2012. Factors affecting the development of workforce versatility. In: 14th IFAC Symposium on information control problems in manufacturing, Bucharest (Romania), pp. 1221-1226. http://www.ifac-papersonline.net/De tailed/53901.html.

Aubron C, Noël L, Lasseur J. 2016. Labor as a driver of changes in herd feeding patterns: evidence from a diachronic approach in Mediterranean France and lessons for agroecology. Ecological Economics 127: 68-79. DOI: 10.1016/j.ecolecon.2016.02.013.

Bellit S, Détang-Dessendre C. 2014. Les salariés agricoles. Entre ancrage sectoriel et précarité. Économie Rurale 342: 87-106.

Bertin J. 1977. La graphique et le traitement graphique de l'information. Paris : Flammarion, $277 \mathrm{p}$.

Bewley J, Palmer RW, Jackson-Smith DB. 2001. An overview of experiences of Wisconsin dairy farmers who modernized their operations. Journal of Dairy Science 84(3): 717-729.

Bitsch V, Getachew AK, Harsh SB, Mugera AW. 2006. Human resource management risks: sources and control strategies based on dairy farmer focus groups. Journal of Agricultural and Applied Economics 38(01): 123-36. DOI: 10.1017/S1074070800022112.

Blanc M, Cahuzac E, Elyakime B, Tahar G. 2008. Demand for onfarm permanent hired labour on family holdings. European Review of Agricultural Economics 35(4): 493-518. DOI: 10.1093/erae/ jbn032.

Cahuzac É, Détang-Dessendre C. 2011. Le salariat agricole. Une part croissante dans l'emploi des exploitations mais une précarité des statuts. Économie Rurale. Agricultures, Alimentations, Territoires 323: 82-92. DOI: 10.4000/economierurale.3050.

Chabanet G, Dedieu B, Servière G, Tchakérian E, Lémery B. 2000. Le salariat partagé : caractéristiques et fonctionnement des groupements d'employeurs en région d'élevage d'Auvergne et du Limousin. Cahiers Agricultures 9(1): 23-28.

Cournut S, Chauvat S. 2012. L'organisation du travail en exploitation d'élevage: Analyse de 630 bilans travail réalisés dans huit filières animales. INRA Productions Animales 25(2): 101-112.

Dedieu B, Servière G, Madelrieux S, Dobremez L, Cournut S. 2006. Comment appréhender conjointement les changements techniques et les changements du travail en élevage ? Cahiers Agricultures 6: 506-513. DOI: 10.1684/agr.2006.0028.

Depoudent C, Grannec M-L, Le Moan L. 2014. Salariat en élevage porcin: synthèse de quatre études bretonnes. Chambre d'agriculture de Bretagne, $12 \mathrm{p}$. Rennes.

Dupré L. 2010. Spécificités du salariat permanent en élevage laitier de montagne: une première approche dans les Alpes du Nord. Cahiers Agricultures 19(5): 366-370. DOI: 10.1684/agr.2010.0423.

Everaere C. 1999. L'autonomie dans le travail : Sens et contresens. In: Actes de l'AGRH: La GRH: Contrôle et Autonomie. Paris, pp. 469480.

Everaere C. 2006. Pour une échelle de mesure de l'autonomie dans le travail. Revue Internationale sur le Travail et la Société 4(2): 105 23.

Everaere C. 2008. La polyvalence et ses contradictions. Revue Française de Gestion Industrielle 27(4): 89-104. 
Gaudart C, Weill-Fassina A. 1999. L'évolution des compétences au cours de la vie professionnelle: Une approche ergonomique. Formation Emploi 67(1): 47-62. DOI: 10.3406/forem.1999.2361.

Girard N, Bellon S, Hubert B, Lardon S, Moulin C-H, Osty P-L. 2001. Categorising combinations of farmers land use practices: an approach based on examples of sheep farms in the South of France. Agronomie 21(5): 435-459.

Greenhalgh J, Tipples R. 2013. Literature review: from human resource management to employment relations-people focussed employers in dairy farming. http://www.onefarm.ac.nz/system/ files/resource downloads/People $\% 20$ Focussed $\% 20$ Employers $\%$ 20PR\%20Lit\%20Review.pdf.

Harrison JL, Getz C. 2015. Farm size and job quality: mixed-methods studies of hired farm work in California and Wisconsin. Agriculture and Human Values 32(4): 617-34. DOI: 10.1007/ s10460-014-9575-6.

Hutt MJ, Hutt GK. 1993. Organizing the human resource: a review of centralization, decentralization and delegation in agricultural business management. Journal of Dairy Science 76(7): 2069-2079.

Hyde J, Stup R, Holden L. 2008. The effect of human resource management practices on farm profitability: an initial assessment. Economics Bulletin 17(12): 1-10.

Hyde J, Cornelisse SA, Holden LA. 2011. Human resource management on dairy farms: does investing in people matter? Economics Bulletin 31(1): 208-217.

Jago J, Ohnstad I, Reinemann DJ. 2007. Labor practices and technology adoption on New Zealand dairy farms. American Society of Agricultural and Biological Engineers. DOI: 10.13031/ 2013.22798.

Krissman F. 1995. Farm labor contractors: The processors of new immigrant labor from Mexico for Californian agribusiness. Agriculture and Human Values 12(4): 18-46. DOI: 10.1007/ BF02218565.

Madelrieux S, Dedieu B, Dobremez L, Girard N. 2009. Patterns of work organisation in livestock farms: the ATELAGE Approach. Livestock Science 121(1): 28-37. DOI: 10.1016/j. livsci.2008.05.014.

Madelrieux S, Dupré L, Rémy J. 2009. Itinéraires croisés et relations entre éleveurs et salariés dans les Alpes du Nord. Économie Rurale. Agricultures, Alimentations, Territoires 313-314: 6-21. DOI: 10.4000/economierurale.2367.

Madelrieux S, Dupré L, Hostiou N, Barbosa T, Bendahan AB, Tourrand J-F. 2010. Liens entre salariat et activité agricole: itinéraires professionnels de salariés d'élevage. Cahiers Agricultures 19(5): 354-358.

Madelrieux S, Depoudent C. 2015. Le salariat en élevage: évolutions, formes, et relations entre éleveurs et salariés. In 4 Rencontre Nationales Travail en Élevage: Recueil Des Contributions. Dijon (France). http://www.afpf-asso.fr/files/fichiers/Recueil_contribu tions_2015.pdf\#page $=28$.

Moffatt J. 2016. Understanding career pathways in agriculture: theorising the farmhand career. Australian Journal of Career Development 25(3): 129-38. DOI: 10.1177/1038416216676605.

Moulin C-H, Pluvinage J, Bocquier F. 2004. Les relations entre agrandissement des troupeaux et changements de conduite: exemple des élevages d'ovins allaitants en Crau. In: Rencontres Recherches Ruminants. Paris. http://journees3r.fr/IMG/pdf/ 2004 agrandissement 04 Moulin.pdf.

Mugera AW, Bitsch V. 2005. Managing labor on dairy farms: a Resourcebased perspective with evidence from case studies. International Food and Agribusiness Management Review 8(3): 79-98.

Mundler P, Laurent C. 2003. Flexibilité du travail en agriculture: Méthodes d'observation et évolutions en cours. Ruralia. Sciences Sociales et Mondes Ruraux Contemporains 12(12/13): 239-57.

Nettle R, Paine M, Petheram J. 2005. The employment relationship: a conceptual model developed from farming case studies. New Zealand Journal of Employment Relations 30(2): 19-35.

Nettle R. 2012. Farmers growing farmers: the role of employment practices in reproducing dairy farming in Australia. In: IFSA International Farming Systems Association. Aarhus (Denmark). http://ifsa.boku.ac.at/cms/fileadmin/Proceeding2012/ IFSA2012_WS3.2_Nettle.pdf.

Porter JC. 1993. What dairy employees think about their jobs. Journal of Dairy Science 76(7): 2065-2068. DOI: 10.3168/jds.S0022-0302 (93)77541-4.

Przewozny A, Bitsch V, Peters KJ. 2016. Performance-based pay and other incentive schemes on dairy farms in Germany. SSRN. DOI: $10.2139 /$ ssrn. 2851082 .

Stup RE, Hyde J, Holden LA. 2006. Relationships between selected human resource management practices and dairy farm performance. Journal of Dairy Science 89(3): 1116-1120. DOI: 10.3168/ jds.S0022-0302(06)72180-4.

Tourmen C. 2007. Activité, tâche, poste, métier, profession : quelques pistes de clarification et de réflexion. Santé Publique 19: 15-20.

Vafaï K, Anvar S. 1998. Délégation et hiérarchie. Revue Économique 49(5): 1199. DOI: 10.2307/3502771.

Cite this article as: Malanski PD, Hostiou N, Ingrand S. 2017. Evolution pathways of employees' work on dairy farms according to task content, specialization, and autonomy. Cah. Agric. 26: 65005. 